\title{
Defective Cellular Immunity in Renal Failure: Depression of Reactivity of Lymphocytes to Phytohemagglutinin by
}

\author{
Renal Failure Serum
}

\author{
W. Marcus Newberry and Jay P. Sanford \\ From the Department of Internal Medicine, The University of Texas \\ Southwestern Medical School at Dallas, Dallas, Texas 75235
}

\begin{abstract}
A B S T RACT In defining host resistance factors in uremia, experiments were designed to assess the effect of renal failure serum upon the reactivity of normal human lymphocytes to phytohemagglutinin in vitro. Normal buffy coat cells were resuspended in sera obtained from normal subjects and from 14 patients with renal failure, then stimulated with phytohemagglutinin $M$ and the cellular response measured by the increase in thymidine or uridine uptake. The mean thymidine uptake by stimulated cells in normal sera was $14,389 \pm 1695$ (SEM) cpm per $2 \times 10^{8}$ lymphocytes. Uridine uptake under the same conditions was $12,540 \pm 1887 \mathrm{cpm}$. Compared to these are a mean thymidine uptake of $2740 \pm 457 \mathrm{cpm}$ and uridine uptake of $3928 \pm 667 \mathrm{cpm}$ in renal failure sera. Both differences are significant at $P<0.01$ level.
\end{abstract}

For controls representing "chronic illnesses," sera from patients with pneumococcal meningitis, cirrhosis of the liver without jaundice, rheumatoid arthritis, and paraplegia with urinary tract infection did not cause suppression. No single drug had been taken by all the renal failure patients; three patients were taking no drugs.

The serum from one patient with acute renal failure suppressed thymidine uptake while her serum obtained after recovery from her illness supported a normal lymphocyte response. Improvement of lymphocyte response was also noted in 9 of 10 sera obtained from patients immediately after hemodialysis. These observations plus the inhibition of stimulated cells by normal serum mixed with renal failure serum indicate the presence of a dialyzable inhibitory factor rather than the absence of a supporting factor in the renal failure sera.

Lymphocytes preincubated for $24 \mathrm{hr}$ in renal failure serum responded normally when transferred to normal serum and stimulated. Cells stimulated in normal serum and transferred to renal failure serum within the initial

\footnotetext{
Received for publication 14 December 1970 and in revised
} form 29 January 1971.
$24 \mathrm{hr}$ of incubation demonstrated depressed thymidine uptake. Also, cell survival for $72 \mathrm{hr}$ incubation as judged by trypan blue exclusion and chromium-51 release was similar in normal and renal failure sera. Thus, the suppressive effect of renal failure serum does not depend upon the initial phytohemagglutinin-cell interaction nor upon a significant cytotoxic effect.

These studies demonstrate that a dialyzable factor(s) in the serum of patients with renal failure can greatly suppress one parameter by which an immune function of circulating lymphocytes is assessed and provides at least, a partial explanation for delayed homograft rejections in renal failure as well as the susceptibility of such patients to various infections.

\section{INTRODUCTION}

Infections represent a major problem in patients with renal failure and uremia (1-3). In attempting to define factors which may provide the basis for this clinical observation, there appear to be multiple potential determinants. Among these could be included increased exposure to the potential hazard of exogenous microbial agents in the hospital environment as well as defective host defense mechanisms. The latter would include those immune mechanisms mediated through B-cell lines by the production of specific immunoglobulins and those mediated through $\mathrm{T}$ (thymic dependent) lymphocytes and defined as cellular immunity. Cellular immunity may be assessed by measuring a series of responses involving the small lymphocyte and mediators released from such lymphocytes in response to specific activation. Because cell-mediated reactions play a major role in the recovery from various infections characterized by intracellular parasitism such as tuberculosis, "coliform" bacillary infections, toxoplasmosis, and viral infections, a defect in cellular immune mechanisms could explain further the 
susceptibility of the uremic patient to various infections regardless of whether such infections were of exogenous or indigenous origin.

Although only limited observations relevant to assessment of cellular immunity are available and some of these are controversial, there are data to suggest that cellular immunity in renal failure is depressed. Wilson, Kirkpatrick, and Talmage observed decreased skin reactivity to tuberculin (PPD), histoplasmin, mumps, and candida antigens in 45 patients with chronic renal failure when the reactions in these patients were compared with the reactions to the same antigens in matched kidney donors who were of similar genetic and environmental background (4). In addition, the patients also had prominent lymphopenia. A second line of evidence for suppressed cell-mediated reactions is derived from studies of homograft rejection. Homograft rejection represents a cellular immune response and delayed graft rejection is observed in organ transplants in uremic subjects (5-7). Third, Lang and associates using Rebuck's skin window technique have demonstrated a poor inflammatory response to diphtheria toxoid in patients with renal failure. The inflammatory reaction was characterized by an absence of lymphocytes and monocytes (8). From these data it is not possible to distinguish whether the impairment in lymphocyte function is due to a primary defect in cellular function or whether the defect is in the host milieu, i.e. renal failure serum may be toxic or inhibitory to cellular function. There are studies which report that renal failure serum depresses lymphocyte function in vitro (9-11). However, Kasakura and Lowenstein found no suppression of thymidine incorporation by normal peripheral blood lymphocytes resuspended in renal failure plasma and stimulated with phytohemagglutinin (9).

To clarify the available discordant data and to elucidate mechanisms which might be responsible for the depression of cellular immunity, the influence of renal failure sera on the in vitro response of normal human peripheral blood lymphocytes to stimulation with phytohemagglutinin was studied. Although phytohemagglutinin is a nonspecific mitogenic agent, it represents a strong standardized stimulus which is capable of inducing many of the cellular events which occur in the course of response to specific antigens. These experiments demonstrate that serum from patients with renal failure depresses the stimulation of DNA and RNA synthesis by normal peripheral blood lymphocytes after exposure to phytohemagglutinin.

\section{METHODS}

Cell preparation and incubation. Blood was obtained by venesection from normal healthy donors. A plastic syringe contained enough heparin to yield 20 units $/ \mathrm{ml}$ of whole blood. The preparation of cells has been previously described
(12). In brief, the heparinized whole blood was centrifuged at $1500 \mathrm{rpm}$ for $5 \mathrm{~min}$ in a benchtop centrifuge. The plasma, buffy coat, and top 3-4 $\mathrm{mm}$ of erythrocytes were transferred to separate tubes, placed vertically in a rack, and allowed to stand motionless for $30-45 \mathrm{~min}$ in a $37^{\circ} \mathrm{C}$ incubator. The leucocyte-rich plasma was then removed and the cells were sedimented by centrifugation at $800 \mathrm{rpm}$ for $10 \mathrm{~min}$. The cells were washed once with phosphate buffered saline (PBS), $\mathrm{pH} \mathrm{7.4,} \mathrm{and} \mathrm{suspended} \mathrm{in} \mathrm{culture} \mathrm{medium} \mathrm{for} \mathrm{total}$ and differential cell counts. The culture medium was Eagle's minimum essential medium $(\mathrm{MEM})^{1}$ with Hanks salts for monolayer cultures (Grand Island Biological Co., Grand Island, N. Y.) with the addition of $2 \mathrm{~mm} \mathrm{L-glutamine,} \mathrm{penicillin}$ $100 \mathrm{U} / \mathrm{ml}$ and streptomycin $100 \mu \mathrm{g} / \mathrm{ml}$. After counting, we adjusted the cell suspension with Eagle's MEM to a concentration of $2 \times 10^{8}$ lymphocytes per $1.5 \mathrm{ml}$. Then $1.5 \mathrm{ml}$ of cell suspension was added to each culture tube which was fitted with a loose cap $(17 \times 100 \mathrm{ml}$, Falcon Plastics, Los Angeles, Calif.). $0.4 \mathrm{ml}$ of either normal homologous or renal failure serum was added to each tube. Blood was obtained on the day of each experiment from a normal healthy donor or a patient with renal failure. The blood was allowed to clot and the serum separated. The serum was then inactivated by heating in a water bath at $56^{\circ} \mathrm{C}$ for $30 \mathrm{~min} . \mathrm{Fi}-$ nally, $0.1 \mathrm{ml}$ of sterile distilled water or phytohemagglutinin ${ }^{\mathrm{M}}$ (PHA-M, Difco Laboratories, Detroit, Mich.) was added to each tube. $5 \mathrm{ml}$ of sterile distilled water had been added to the lyophilized PHA-M. After thorough mixing, we divided the solution into $0.5 \mathrm{ml}$ portions and froze them at $-70^{\circ} \mathrm{C}$. On the day of each experiment, a portion was thawed and $1 \mathrm{ml}$ of sterile distilled water added. Thus, 0.1 $\mathrm{ml}$ of this dilution in each culture tube yielded a final PHA-M concentration of $1: 60$. Parallel sets of tubes with each condition in triplicate were identical except that one set contained normal homologous serum and the other set renal failure serum. For some experiments, enough lymphocytes were obtained to evaluate more than one renal failure serum with a single normal serum. However, during the course of this study many additional normal sera were evaluated. The cultures were maintained in a $37^{\circ} \mathrm{C}, 5 \%$ carbon dioxide, humidified atmosphere for $72 \mathrm{hr}$.

$D N A$ synthesis. During the last $1 \mathrm{hr}$ of incubation, 2 $\mu \mathrm{Ci}$ of methylthymidine ${ }^{3} \mathrm{H}$ (SA $6.7 \mathrm{Ci}$ per mu, New England Nuclear Corp., Boston, Mass.) was added to each tube. After the additional hour of incubation, the tubes were placed in an ice bath. They were then centrifuged at $5^{\circ} \mathrm{C}$. The cells were washed twice with cold PBS, lysed, and then precipitated with $3 \mathrm{ml}$ of cold $5 \%$ trichloroacetic acid (TCA). The precipitate was washed once with cold $5 \%$ TCA and once with cold absolute methanol, which was then decanted. The tubes were inverted and allowed to air dry. Then $0.5 \mathrm{ml}$ of $2 \mathrm{~N} \mathrm{NaOH}$ was added to digest the precipitate. $0.1 \mathrm{ml}$ of the digested material was transferred to a scintillation vial (Beckman, Fullerton, Calif.) to which was added $0.4 \mathrm{ml}$ of fresh $2 \mathrm{~N} \mathrm{NaOH}$ and the volume of acidic solubilizer (BBS-2, Beckman) needed to achieve a neutral $\mathrm{pH}$ (usually $1.3 \mathrm{ml}$ ). The contents were thoroughly mixed on a vortex mixer. $10 \mathrm{ml}$ of scintillation fluid $(2,5-$ diphenyloxazole [6 g], $p$-bis[2-(5-phenyloxazolyl)]-benzene [100 mg], toluene [to 1 liter]) was added to each vial. The vials were again mixed on a vortex mixer. Blanks consisted of tubes incubated and treated as above except that no radioactive label was added. After standing overnight the

${ }^{1}$ Abbreviations used in this paper: MEM, minimum essential medium; PBS, phosphate buffered saline; PHA, phytohemagglutinin; TCA, trichloroacetic. 
vials were counted with limits of 40,000 total counts or 10 $\min$ in a Beckman liquid scintillation counter (LA-200), efficiency for tritium $27 \%$. Results were expressed as mean counts per minute, cpm, per $2 \times 10^{6}$ lymphocytes with the blanks subtracted.

$R N A$ synthesis. The effect of renal failure upon the RNA response of stimulated normal lymphocytes was also determined. For these experiments, the cells were prepared as previously described except that the incubation period was limited to $24 \mathrm{hr}$. During the last $1 \mathrm{hr}$ of culture, $5 \mu \mathrm{Ci}$ of uridine-5- ${ }^{3} \mathrm{H}$ (SA $26.2 \mathrm{Ci}$ per mM, New England Nuclear) was added to each tube. At $24 \mathrm{hr}$ the cells were treated as previously described for thymidine uptake.

Cell viability. Cell viability was determined by cell counts with trypan blue of unstimulated cultures in both normal and renal failure serum. Cells were prepared and incubated as described for DNA synthesis. After $72 \mathrm{hr}$ of incubation the tubes were centrifuged, the culture media decanted, and the cells suspended in $2 \mathrm{ml}$ normal saline. Total cell counts were performed. In addition, three drops of the cell suspension were mixed with one drop of $1 \%$ trypan blue. The number of stained cells among 200 cells was counted after waiting $15 \mathrm{~min}$ (13).

Cytotoxicity of the culture conditions was further tested by a method adapted from Rogentine and Plocinik (14). $2 \mathrm{~g}$ of washed spun glass (Owens-Corning Fiberglass Corp., Toledo, Ohio) was packed tightly into a $10 \mathrm{ml}$ glass syringe barrel and autoclaved. A three-way stopcock was attached to the syringe. This column was placed in a $37^{\circ} \mathrm{C}$ incubator and void volume portions of leucocyte-rich plasma were placed on the column for 15 -min periods with each portion being displaced by another. The last portion was displaced from the column with PBS but the column was not washed further. The cells were sedimented by centrifugation and the contaminating erythrocytes were lysed by first suspending the cell button in $2 \mathrm{ml}$ of cold PBS and then rapidly adding $5 \mathrm{ml}$ cold distilled water. The suspension was agitated for $30 \mathrm{sec}$ and isotonicity was restored with $1.5 \mathrm{ml}$ of cold 5 times concentrated PBS. The suspension was centrifuged and the sedimented cells diluted with $5 \mathrm{ml}$ Eagle's MEM containing $15 \%$ normal serum by volume for total and differential cell count. This technique yielded populations which were 95-97\% lymphocytes. Sodium chromate${ }^{51} \mathrm{Cr}$ (SA $65 \mathrm{mCi} / \mathrm{mg}$, New England Nuclear) $40 \mu \mathrm{Ci}$ per $50 \times 10^{8}$ lymphocytes was added and the suspension incubated in a $37^{\circ} \mathrm{C}$ water bath with constant gentle agitation for $30 \mathrm{~min}$. The cells were washed three times with cold PBS and distributed into culture tubes as previously described for DNA synthesis. After $72 \mathrm{hr}$ incubation, the tubes were centrifuged and the supernatant carefully removed from each tube, placed into counting tubes, and counted for 10 -min periods in an automatic gamma radiation counter (Packard Instruments, Downers Grove, I1l.). In each experiment, tubes containing $2 \times 10^{6}$ lymphocytes were frozen and thawed rapidly four times and centrifuged for $10 \mathrm{~min}$ at $1500 \mathrm{~g}$. This freeze-thaw supernatant radioactivity was arbitrarily set equal to $100 \%$ release. The amount of ${ }^{51} \mathrm{Cr}$ released in the reaction tubes was expressed as a per cent of the $100 \%$ release counts.

\section{RESULTS}

Sera from 13 patients with chronic renal failure and 1 patient with acute renal failure have been studied ( $\mathrm{Ta}$ ble I). Of those patients with chronic renal failure, nine had glomerulonephritis, two had malignant hypertension, one had both diabetes mellitus and congestive heart failure, and the etiology of renal failure in one case was unknown. The patient with acute renal failure had postabortal clostridial sepsis associated with intravascular hemolysis from which she completely recovered. At the time serum was obtained all of the patients except one had severe renal failure with serum creatinine concentrations of $13.6 \mathrm{mg} / 100 \mathrm{ml}$ or greater. Detailed drug histories revealed no single drug which all of the patients had in common and three patients were taking no drugs when the serum samples were obtained.

The thymidine incorporation of normal lymphocytes stimulated with phytohemagglutinin $M$ in normal sera and in the renal failure sera is summarized in Fig. 1. The mean thymidine incorporation by lymphocytes incubated in normal sera was $14,389 \pm 1695$ (SEM) cpm, while that of lymphocytes incubated in renal failure sera was $2740 \pm 457 \mathrm{cpm}(P<0.001)$. There is no overlap between any result in normal serum with that obtained in renal failure serum. There was a trend for greater suppression with higher creatinine and urea

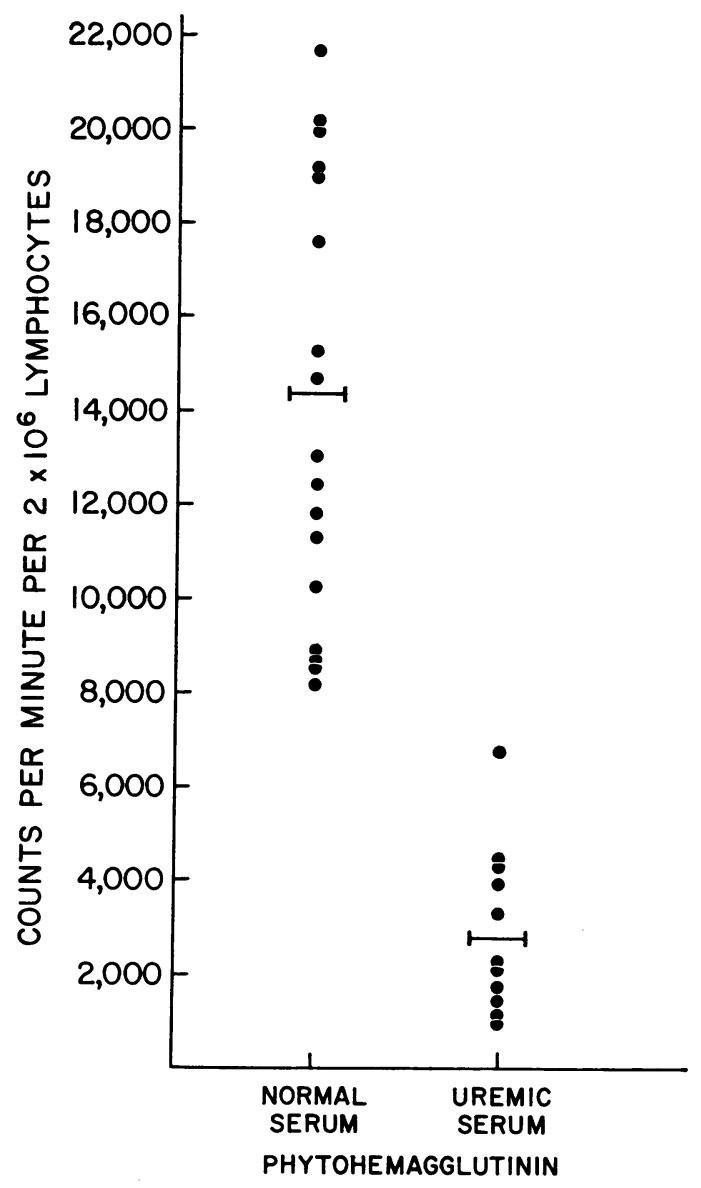

FIGURE 1 Thymidine uptake by stimulated normal lymphocytes in normal and renal failure sera. 
TABLE I

Response of Normal Human Lymphocytes Stimulated with Phytohemagglutinin in Normal and Renal Failure Sera

\begin{tabular}{|c|c|c|c|c|c|c|c|c|c|}
\hline \multirow[b]{2}{*}{$\begin{array}{l}\text { Renal } \\
\text { failure } \\
\text { patient }\end{array}$} & \multirow[b]{2}{*}{$\begin{array}{c}\text { Blood } \\
\text { urea } \\
\text { nitrogen }\end{array}$} & \multirow[b]{2}{*}{$\begin{array}{c}\text { Serum } \\
\text { creatinine }\end{array}$} & \multirow[b]{2}{*}{$\begin{array}{c}\text { Etiology } \\
\text { of renal } \\
\text { failure }\end{array}$} & \multirow[b]{2}{*}{$\begin{array}{c}\text { Duration } \\
\text { of renal } \\
\text { failure }\end{array}$} & \multirow[b]{2}{*}{ Drugs* } & \multicolumn{2}{|c|}{ Thymidine uptake } & \multicolumn{2}{|c|}{ Uridine uptake } \\
\hline & & & & & & $\begin{array}{l}\text { Normal } \\
\text { serum }\end{array}$ & $\begin{array}{c}\text { Renal } \\
\text { failure } \\
\text { serum }\end{array}$ & $\begin{array}{l}\text { Normal } \\
\text { serum }\end{array}$ & $\begin{array}{l}\text { Renal } \\
\text { failure } \\
\text { serum }\end{array}$ \\
\hline C. Dev. & $\begin{array}{c}m g / 100 \mathrm{ml} \\
106\end{array}$ & $\begin{array}{c}m g / 100 \mathrm{ml} \\
20.8\end{array}$ & CGN & $\begin{array}{c}y r \\
? 18\end{array}$ & $\begin{array}{l}\text { Apresoline } \AA \\
\text { Aldomet } \AA \\
\text { Chlorthalidone } \\
\text { Allopurinol }\end{array}$ & 21,643 & $\begin{array}{c}n \text { per } 2 \times \\
987\end{array}$ & lymphocyte & \\
\hline M. H. & 63 & 18.2 & CGN & 13 & 0 & 13,002 & 1195 & & 3072 \\
\hline J.A. & 85 & 18.2 & CGN & 12 & $\begin{array}{l}\text { Coumadin } ₫ \\
\text { Aldomet } \circledast\end{array}$ & $18,931 \ddagger$ & 1429 & & \\
\hline D. B. & 59 & 14.0 & CGN & 12 & 0 & 8,708 & 3932 & & . \\
\hline F. K. & 51 & 8.8 & HCVD & 11 & $\begin{array}{l}\text { Chlorothiazide } \\
\text { Reserpine } \\
\text { Ismelin® }\end{array}$ & & & 10,031 & 4943 \\
\hline G. F. & 120 & 13.1 & CGN & 10 & $\begin{array}{l}\text { Lomotil }{ }^{\circledR} \\
\text { Seconal } \\
\text { Cloxacillin } \\
\text { Darvon® }\end{array}$ & 10,247 & 1132 & 14,451 & 1499 \\
\hline C. Dea. & 130 & 20.0 & CGN & 10 & $\begin{array}{l}\text { Chloram- } \\
\text { phenicol }\end{array}$ & $18,931 \ddagger$ & 2083 & & \\
\hline J. T. & 150 & 24.0 & CGN & 9 & $\mathbf{0}$ & 12,464 & 1728 & & \\
\hline M. V. & 43 & 3.7 & $\begin{array}{l}\text { DM } \\
\text { CHF }\end{array}$ & 7 & $\begin{array}{l}\text { Digoxin } \\
\text { Chlorothiazide } \\
\text { Orinase } \&\end{array}$ & $11,290 \ddagger$ & 6739 & & \\
\hline L. H. & 139 & 18.1 & CGN & 2 & $\begin{array}{l}\text { Aldomet } \circledast \\
\text { Amphojel® }\end{array}$ & 8,183 & 4483 & 5,812 & 4404 \\
\hline K. R. & 155 & 14.2 & HCVD & $\frac{1}{2}$ & $\begin{array}{l}\text { Chlorothiazide } \\
\text { Aldomet } \$ \\
\text { Ismelin } \AA\end{array}$ & $18,931 \ddagger$ & 2295 & $14,451^{*}$ & 5722 \\
\hline D. Bry. & 82 & 18.7 & ? & ? & Gentamicin & $11,290 \ddagger$ & 4333 & & \\
\hline W. W. & 75 & 14.0 & $\mathrm{CGN}$ & $?$ & Chlorothiazide & $11,816 \ddagger$ & 3284 & & \\
\hline S. R. & 168 & 13.6 & Acute & 2 wk & Penicillin & $\begin{array}{r}11,816 \ddagger \\
20,127 \\
8902 \\
18,481 \\
8573 \\
19,141 \\
15,227 \\
17,568 \\
19,997 \\
14,701\end{array}$ & 2000 & $\begin{array}{l}17,656 \\
14,752\end{array}$ & \\
\hline
\end{tabular}

CGN, chronic glomerulonephritis; HCVD, hypertensive cardiovascular disease; DM, diabetes mellitus; CHF, congestive heart failure.

Drugs and manufacturers as follows: Apresoline (hydrochloride), CIBA Pharmaceutical Co., Summit, N. J.; Aldomet, Merck Sharpe \& Dohme, Division of Merck \& Co., Inc., West Point, Pa.; Coumadin, Endo Laboratories, Inc., 100 Stewart Ave., Garden City, N. Y.; Ismelin, CIBA Pharmaceutical Co., Div. of CIBA Corp., 556 Morris Ave., Summit, N. J.; Lomotil, Searle \& Co., GD, P. O. Box 5110, Chicago, Ill.; Seconal, Lilly and Company, Eli, 307 East McCarty Street, Indianapolis, Ind.; Darvon (Lilly \& Company); Orinase, The Upjohn Company, Kalamazoo, Mich.; Amphojel, Wyeth Laboratories, Division of American Home Products Corp., P. O. Box 8299, Philadelphia, Pa.

† Single experiment with one cell and normal serum donor but more than one renal failure serum donor. 


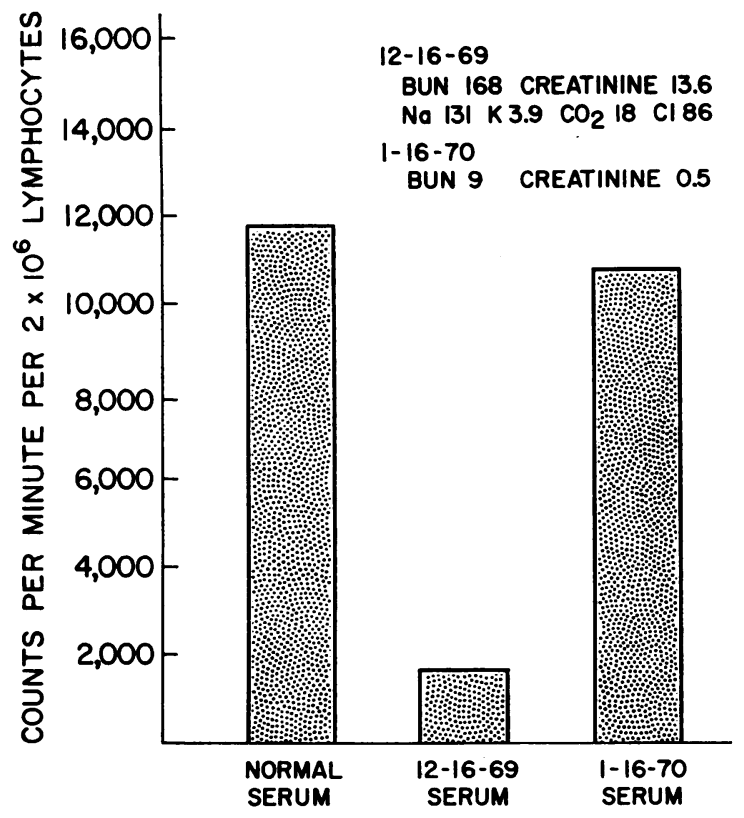

FIGURE 2 The response of stimulated normal lymphocytes cultured in normal, acute renal failure, and postrecovery phase sera.

nitrogen levels. The variation in thymidine incorporation by stimulated lymphocytes in normal sera represents the difference between cell donors. The variability in results obtained using the same cell donors on different days and in different normal sera was not greater than 1200 $\mathrm{cpm}$. The thymidine incorporation by unstimulated cells was similar in normal and renal failure sera with mean values of 20 and $21 \mathrm{cpm}$, respectively.

To evaluate the effect of varying the strength of cell stimulation, experiments were done with PHA at concentrations between $1: 20$ and $1: 1200$. Although absolute differences in thymidine incorporation occurred at differing PHA concentrations with slight depression presumably related to toxicity at the highest concentration $(1: 20)$, and erratic stimulation at the lowest con-

TABLE II

Response of Normal Human Lymphocytes Stimulated with Phytohemagglutinin in Sera from Patients with Other Diseases But No Renal Failure

\begin{tabular}{llc}
\hline Patient & \multicolumn{1}{c}{ Disease } & $\begin{array}{c}\text { Thymidine } \\
\text { uptake* }\end{array}$ \\
\hline J. P. & Pneumococcal meningitis & 9,804 \\
B. M. & Hepatic cirrhosis & 10,644 \\
J. W. & Rheumatoid arthritis & 21,000 \\
G. W. & Urinary tract infection & 15,644
\end{tabular}

Response in normal serum $14,389 \pm 1695 \mathrm{cpm}$.

* cpm per $2 \times 10^{6}$ lymphocytes. centration $(1: 1200)$, varying the concentration of PHA between these extremes did not significantly change the difference in response between normal and renal failure sera. Since the variation was least at a PHA dilution of $1: 60$; this ratio was employed throughout these studies.

The effect of sera from five patients with renal failure upon RNA synthesis by lymphocytes stimulated with PHA-M was evaluated and is also shown in Table I. In each instance the response in renal failure serum was less than in normal serum. The mean uridine $-5{ }^{8} \mathrm{H}$ incorporation in normal serum for unstimulated cells was $1176 \pm 157$ (SEM) cpm and for stimulated lymphocytes, $12,540 \pm 1887 \mathrm{cpm}$. Unstimulated cells in renal failure sera yielded a mean of $628 \pm 67 \mathrm{cpm}$ and stimulated cells responded with $3928 \pm 667 \mathrm{cpm}(P<0.01)$.

The serum obtained from one patient during acute renal failure was maintained along with a normal serum sample at $-70^{\circ} \mathrm{C}$ until a sample was obtained after the patient's recovery and then the three sera were evaluated in simultaneous parallel cultures. These results are shown in Fig. 2. The prominent depression of DNA synthesis in acute illness phase serum was not seen in serum obtained after recovery 1 month later.

To evaluate the possibility that factors other than renal failure might have been responsible for the observed depression of thymidine uptake, normal cells were stimulated in medium containing serum from patients with various other types of illnesses; these included patients with pneumococcal meningitis, cirrhosis of the liver without jaundice, rheumatoid arthritis, and paraplegia with urinary tract infection. The patients were taking penicillin, thiazide diuretics, aspirin, and gentamicin when serum samples were obtained. The patient with

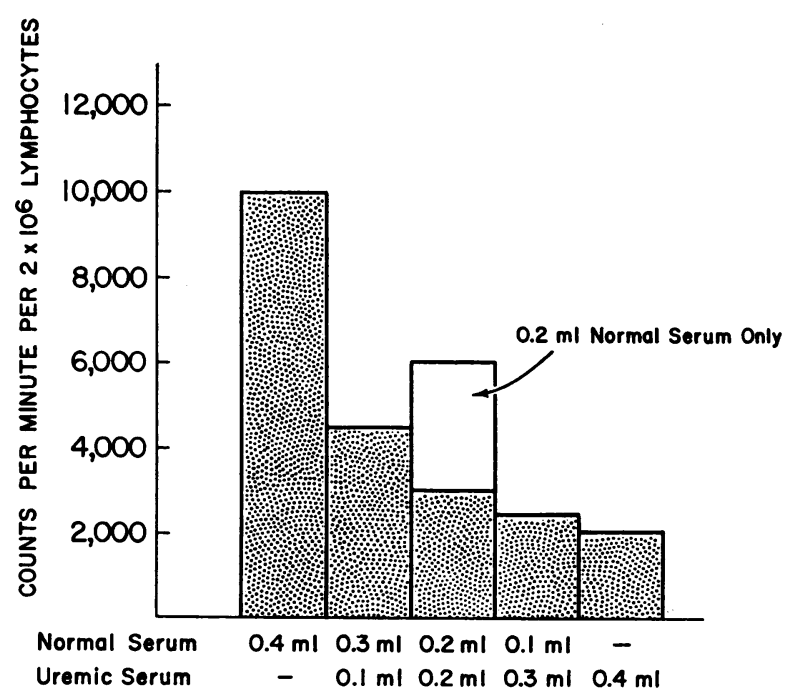

Figure 3 The response of stimulated normal lymphocytes cultured in mixtures of normal and uremic sera. 
pneumococcal meningitis was severely ill, with respiration sustained by a ventilator. In each instance, the response obtained was within the normal range (Table II).

To determine if the observed suppression of DNA synthesis by stimulated lymphocytes in renal failure serum was due to the presence of an inhibiting factor(s) or the absence of a supporting factor(s), cells were incubated in simultaneous cultures comparing the effects of diluting renal failure serum by normal serum with the effect of decreasing the amount of normal serum alone in the culture tubes. These results are summarized in Fig. 3. The incorporation of radiolabeled thymidine was less in cell cultures containing $20 \%$ serum, consisting of $0.2 \mathrm{ml}$ normal serum and $0.2 \mathrm{ml}$ renal failure serum, than in cell cultures containing $0.2 \mathrm{ml}$ normal serum only $(10 \%)$.

10 of the 13 patients studied were on a chronic hemodialysis program. Table III and Fig. 4 show the response of normal lymphocytes stimulated in sera obtained immediately before and immediately after approximately $6 \mathrm{hr}$ of hemodialysis. In every instance except one, the hemodialysis improved the ability of the patient's serum to support thymidine incorporated by the lymphocyte with PHA-M stimulation. The degree of improvement could not be correlated to any definite parameter of the disease process. Although the two patients whose posthemodialysis sera supported a lymphocyte response within the normal range had the shortest duration of chronic renal failure among the patients studied, this relationship could not be successfully applied in other instances, possibly because eight of the patients had much longer durations of renal failure.

Preincubation experiments were performed to determine if renal failure serum can irreversibly depress lym-

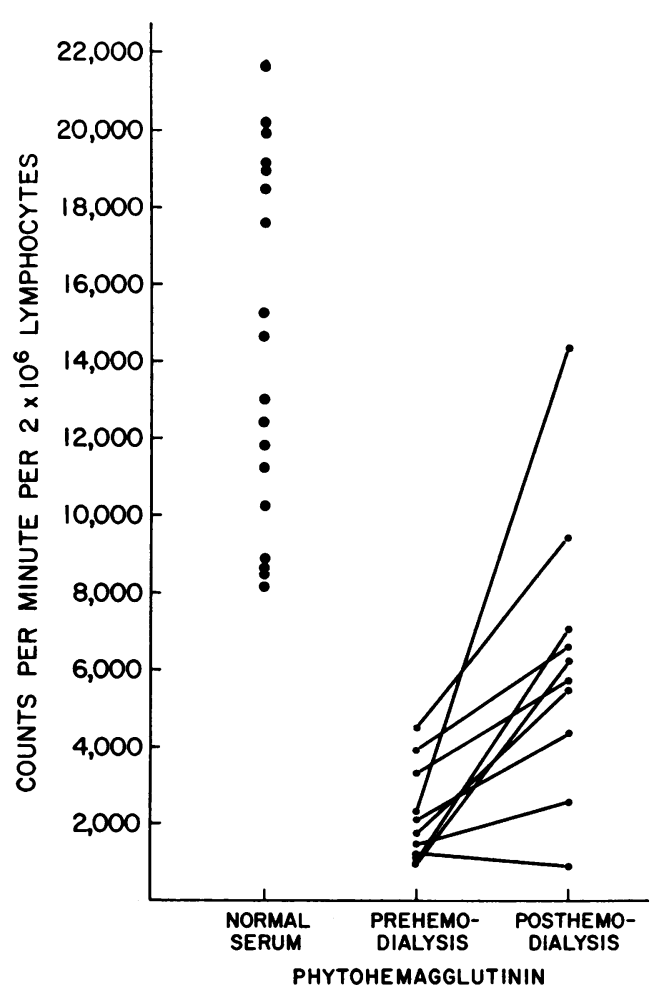

FIgURE 4 Thymidine uptake by stimulated normal lymphocytes cultured in normal sera and pre- and posthemodialysis sera.

phocyte response. Triplicate sets of tubes, each containing $2 \times 10^{8}$ lymphocytes, were incubated for 24 and 72 $\mathrm{hr}$ in culture medium containing normal or renal failure serum but no phytohemagglutinin. At the completion of the preincubation periods, the medium was removed and replaced with fresh medium containing normal or renal

TABLE III

Response of Normal Lymphocytes Stimulated with Phytohemagglutinin in Freand Posthemodialysis Sera

\begin{tabular}{|c|c|c|c|c|c|c|c|}
\hline \multirow{2}{*}{$\begin{array}{l}\text { Renal } \\
\text { failure } \\
\text { patient }\end{array}$} & \multicolumn{2}{|c|}{ Prehemodialysis } & \multicolumn{2}{|c|}{ Posthemodialysis } & \multicolumn{2}{|c|}{ Thymidine uptake } & \multirow{2}{*}{$\begin{array}{c}\text { Duration } \\
\text { of } \\
\text { illness }\end{array}$} \\
\hline & $\begin{array}{c}\text { Urea } \\
\text { nitrogen }\end{array}$ & Creatinine & $\begin{array}{c}\text { Urea } \\
\text { nitrogen }\end{array}$ & Creatinine & $\begin{array}{c}\text { Prehemo- } \\
\text { dialysis }\end{array}$ & $\begin{array}{c}\text { Posthemo- } \\
\text { dialysis }\end{array}$ & \\
\hline & \multicolumn{2}{|c|}{$m g / 100 m l$} & \multicolumn{2}{|c|}{$m g / 100 m l$} & \multicolumn{2}{|c|}{$c p m / 2 \times 10^{6}$ lymphocytes } & $y r$ \\
\hline C. Dev. & 106 & 20.8 & 53 & 10.7 & 987 & 6,205 & 18 \\
\hline M. H. & 63 & 18.2 & 22 & 5.8 & 1195 & 890 & 13 \\
\hline J. A. & 85 & 18.2 & 46 & 9.9 & 1429 & 2,592 & 12 \\
\hline D. B. & 59 & 14.0 & 28 & 7.5 & 3932 & 6,603 & 12 \\
\hline G. F. & 120 & 13.1 & 55 & 7.1 & 1132 & 7,057 & 10 \\
\hline C. Dea. & 130 & 20.0 & 68 & 11.7 & 2083 & 4,389 & 10 \\
\hline J. T. & 150 & 24.0 & 70 & 11.5 & 1728 & 5,506 & 9 \\
\hline L. H. & 138 & 18.1 & 91 & 11.7 & 4483 & 9,430 & 2 \\
\hline K. R. & 155 & 14.2 & 69 & 7.2 & 2295 & 14,371 & $\frac{1}{2}$ \\
\hline W. W. & 75 & 14.0 & 31 & 7.5 & 3284 & 5,761 & $?$ \\
\hline
\end{tabular}




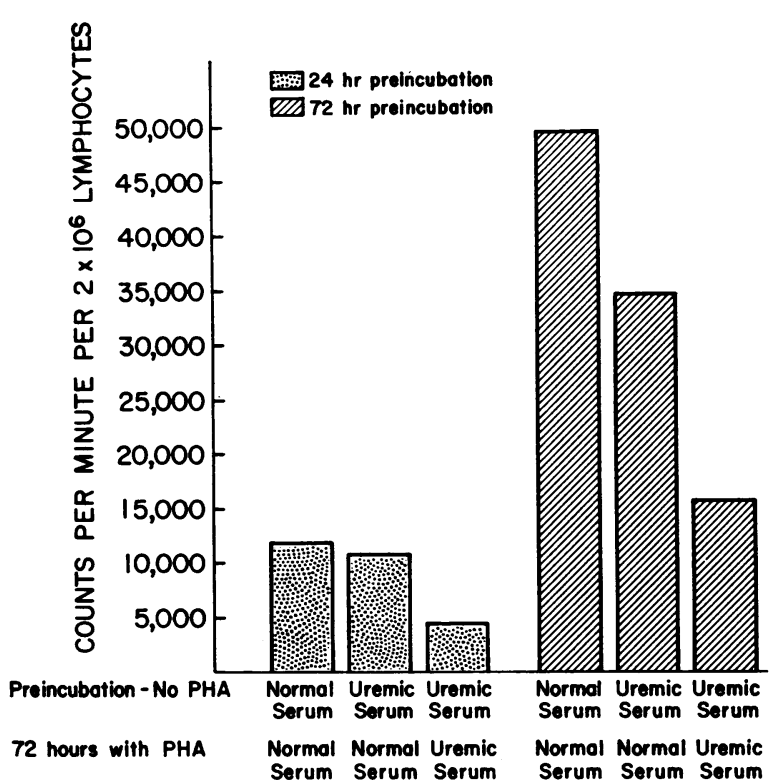

FIGURE 5 The response of stimulated normal lymphocytes following 24 and $72 \mathrm{hr}$ in vitro preincubation in normal and renal failure serum.

failure serum plus PHA-M and the incubation continued for an additional $72 \mathrm{hr}$. Each experiment contained one set of triplicate tubes in which cells were changed from normal serum to normal serum, another set of triplicate tubes in which cells were changed from renal failure serum to normal serum, and another set of triplicate tubes in which cells were changed from renal failure serum to renal failure serum. Fig. 5 shows the results from an experiment typical of several that evaluate the effect of preincubation. $24 \mathrm{hr}$ of preincubation in renal failure serum before PHA-M stimulation in normal

\section{TABLE IV}

The Effect of Uremic Serum upon Normal Lymphocytes in the Active State of Transformation

\begin{tabular}{|c|c|c|c|c|}
\hline \multicolumn{2}{|c|}{ Initial media with PHA } & \multicolumn{2}{|c|}{ Second media without PHA } & \multirow{2}{*}{$\begin{array}{l}\text { cpm per } \\
\text { tube }\end{array}$} \\
\hline Serum & Duration & Serum & Duration & \\
\hline & $h r$ & & $h r$ & \\
\hline Normal & 72 & & & 10,247 \\
\hline Normal & 1 & Normal & 71 & 9,799 \\
\hline Normal & 6 & Normal & 66 & 11,527 \\
\hline Normal & 24 & Normal & 48 & 8,471 \\
\hline Normal & 48 & Normal & 24 & 9,481 \\
\hline Uremic & 72 & & & 5,718 \\
\hline Normal & 1 & Uremic & 71 & 5,190 \\
\hline Normal & 6 & Uremic & 66 & 5,775 \\
\hline Normal & 24 & Uremic & 48 & 3,959 \\
\hline Normal & 48 & Uremic & 24 & 12,162 \\
\hline
\end{tabular}

serum did not inhibit the ability of lymphocytes to respond in a manner similar to cells preincubated in normal serum. Preincubation and stimulation in renal failure serum resulted in the lowest counts. After $72 \mathrm{hr}$ preincubation in renal failure serum followed by stimulation in normal serum, the response was depressed below the response seen with $72 \mathrm{hr}$ preincubation in normal serum. As previously noted, the thymidine incorporation became greater for all cells with longer periods of preincubation in either type of serum (15).

Table IV shows the result of an experiment which is typical of several demonstrating that renal failure serum is capable of inhibiting the incorporation of tritiated thymidine by lymphocytes already in the active state of transformation. Cell cultures were initiated in medium containing normal serum and PHA-M. Medium changes were performed at $1,6,24$, and $48 \mathrm{hr}$ to fresh medium containing normal or renal failure serum but no PHA-M and the incubation continued for the remainder of $72 \mathrm{hr}$. Cells which were undisturbed for 72 $\mathrm{hr}$ in medium with normal serum incorporated 10,247 cpm. Medium changes at $1,6,24$, and $48 \mathrm{hr}$ to fresh medium with normal serum yielded similar counts. Cells undisturbed for $72 \mathrm{hr}$ in medium with renal failure serum incorporated $5718 \mathrm{cpm}$. Change from medium containing normal serum to medium containing renal failure serum at 1,6 , and $24 \mathrm{hr}$ also demonstrated depressed incorporation of counts. The medium change at $48 \mathrm{hr}$ with renal failure serum present only during the last $24 \mathrm{hr}$ of culture incorporated $12,162 \mathrm{cpm}$.

Cultures were pulse-labeled for 1,3 , and $6 \mathrm{hr}$ to study both the possible interference in uptake of thymidine label by the renal failure serum and the effect of asynchrony in cell cultures. Despite longer labeling periods, marked suppression of thymidine uptake by normal cells in renal failure serum was still evident (Table V). Thymidine uptake by cells in renal failure serum was a linear function of the labeling period.

\section{TABLE V}

The Effect of Varying Pulse Label Periods upon Response Evaluation of Stimulated Lymphocytes

\begin{tabular}{cccccr}
\hline \multicolumn{2}{c}{ Serum } & & & & \\
Normal & $\begin{array}{c}\text { Renal } \\
\text { failure }\end{array}$ & PHA & $\begin{array}{c}\text { Incuba- } \\
\text { tion }\end{array}$ & Pulse & cpm \\
\hline & & & $h r$ & $h r$ & \\
+ & - & $1: 60$ & 72 & 1 & 19,997 \\
+ & - & $1: 60$ & 72 & 3 & 56,919 \\
+ & - & $1: 60$ & 72 & 6 & 82,788 \\
- & + & $1: 60$ & 72 & 1 & 4,784 \\
- & + & $1: 60$ & 72 & 3 & 16,440 \\
- & + & $1: 60$ & 72 & 6 & 26,794 \\
\hline
\end{tabular}


The survival of unstimulated cells for $72 \mathrm{hr}$ in normal and renal failure serum was evaluated in four separate experiments using the trypan blue staining and chromium-51 release technique (Table VI). By means of trypan blue, $25 \%$ of the cells were not viable in both normal and renal failure sera. Chromium-51 release indicated $46 \%$ cell death in normal sera and $47 \%$ cell death in renal failure sera.

Attempts at in vitro dialysis utilizing colloidin bags were unsuccessful in that normal sera which had been dialyzed or even incubated in the bags were toxic to cell culture. This was true even when the bags were boiled in water containing sodium bicarbonate and rinsed exhaustively with distilled water.

\section{DISCUSSION}

These observations clearly show that sera from patients with renal failure suppress at least two important parameters of lymphocyte response to phytohemagglutinin, namely DNA and RNA synthesis. Furthermore, these data provide strong support for the hypothesis that suppression of lymphocyte function is due, at least in part, to the milieu in which the lymphocyte must function. This conclusion is based upon a series of observations from this study. First, the experimental design involved the comparison of peripheral blood lymphocytes obtained from a single normal healthy donor, which were then studied after resuspension in homologous renal failure and normal serum. Under these circumstances, uniform suppression of both DNA and RNA synthesis was observed in the lymphocytes suspended in renal failure sera. Second, an improvement in the responsiveness of lymphocytes, when suspended in sera obtained after hemodialysis compared with prehemodialysis sera, was observed in every instance except one. Third, if stimulated cells are transferred from normal serum to renal failure serum within the initial $24 \mathrm{hr}$ of a $72 \mathrm{hr}$ incuba-

\section{TABLE VI}

Trypan Blue Staining and Chromium-51 Release of Unstimulated Normal Lymphocytes Incubated $72 \mathrm{hr}$ in Normal and Renal Failure Sera

\begin{tabular}{lccc}
\hline \multicolumn{2}{c}{ Serum } & $\begin{array}{c}\text { \% of trypan } \\
\text { blue-posi- } \\
\text { tive cells }\end{array}$ & $\begin{array}{c}\text { \% }^{\text {B1 }} \mathrm{Cr} \\
\text { released }\end{array}$ \\
\hline Normal & Renal failure & 25 & 45 \\
M. N. & & 29 & 47 \\
D. G. & & 25 & 44 \\
J. B. & & 22 & 46 \\
L. H. & D. B. & 22 & 44 \\
& M. H. & 21 & 43 \\
& C. Dev. & 27 & 50 \\
& J. A. & 30 & 50 \\
\hline
\end{tabular}

tion period, the thymidine uptake of cells is suppressed.

There are several mechanisms which might be responsible for the deleterious influence of renal failure serum upon lymphocyte function. Foremost to consider is the possibility that renal failure serum is directly toxic to lymphocytes and that there is a significant derease in number of lymphocytes during the course of study. The observations of lymphopenia and shortened in vitro survival of lymphocytes from the uremic host could be interpreted as evidence compatible with direct cytotoxicity $(4,16-18)$. In the present studies, controls to assess cell viability in normal as compared with uremic sera utilizing two techniques, trypan blue exclusion and ${ }^{51} \mathrm{Cr}$ release, both failed to show any differences in loss of viability by lymphocytes when incubated in uremic and normal serum. In addition, the observation that $24 \mathrm{hr}$ preincubation in renal failure serum with subsequent change to normal serum for $72 \mathrm{hr}$ did not result in suppression of DNA synthesis is evidence against cytotoxicity in that the cell numbers were not readjusted between tubes containing uremic and normal serum at time of transfer. Likewise, the experiments in which it was demonstrated that after $48 \mathrm{hr}$ of stimulation in normal serum, replacement with renal failure serum failed to inhibit DNA synthesis weighs against a cytotoxic factor in renal failure sera. Further, $24 \mathrm{hr}$ would appear to be sufficient time to demonstrate any significant cytotoxic effect, as RNA synthesis of stimulated cells was suppressed by renal failure serum after only $24 \mathrm{hr}$ incubation. Thus, the differences in DNA and RNA synthesis observed between renal failure and normal sera cannot be attributed to differences in cell numbers secondary to cytotoxicity during culture.

The second mechanism which should be considered is the possibility that renal failure serum inactivates or in some way binds phytohemagglutinin $M$ rendering it unable to bind to the lymphocyte. This possibility was excluded by the experiments in which the stimulation was initiated with cells in normal serum which were transferred after $24 \mathrm{hr}$ into renal failure serum, then the incubation continued an additional $48 \mathrm{hr}$ with resultant suppression of thymidine uptake. Similar transfer from normal serum to normal serum resulted in no suppression.

Furthermore, the effect of renal failure serum cannot be explained by interference with the uptake of the radioactive label. Experiments yielded normal responses when cells were stimulated and incubated in normal serum for $48 \mathrm{hr}$ followed by transfer to medium containing renal failure serum for the final $24 \mathrm{hr}$ of incubation. The final $24 \mathrm{hr}$ of incubation includes the labeling period.

Another possible mechanism is that of a toxic action on the part of one or more drugs on lymphocyte function. Detailed review of drug histories revealed no drugs in 
common to all patients; three patients were taking no drugs. Hence this cannot be invoked as an explanation.

Since neither loss of cell viability, failure of the phytohemagglutinin, nor drug toxicity can be evoked to account for the observed suppression, renal failure serum itself would seem to be responsible. Renal failure serum might be deficient in some factor necessary for lymphocyte function or, as an alternative, might contain an inhibitory substance or substances. The dilution studies, in which it was demonstrated that DNA synthesis was less in a mixture of $0.1 \mathrm{ml}$ of uremic serum plus $0.3 \mathrm{ml}$ of normal serum than even in $0.2 \mathrm{ml}$ of normal serum, would seem to effectively exclude a "deficiency" as the causative mechanism.

Thus, we feel that these studies support the hypothesis that a factor or factors retained by poorly functioning kidneys are responsible for the altered cellular responsiveness to phytohemagglutinin. The factor does not appear to be related to the type of renal disease since the patients had a variety of types varying from chronic glomerulonephritis to acute tubular necrosis secondary to septic abortion. The correlation of the degree of lymphocyte suppression with serum levels of creatinine and urea nitrogen suggest that the magnitude as well as the duration of renal failure is important in determining the level of the suppressive factor. The improvement in cellular response in posthemodialysis sera and serum obtained promptly after recovery from acute renal failure suggests that the factor(s) are dialyzable.

The nature of such a factor has not been defined; it would not appear, however, to be urea or creatinine per se. The observation that small mononuclear cells within the renal medulla are capable of normal immunoglobulin synthesis would provide data which mitigate against a primary role of urea or creatinine (19). Other investigators have demonstrated that metabolic degradation products, methylguanidine and guanidinosuccinic acid, are retained by poorly functioning kidneys (20-23) and are responsible in part for alteration of platelet and certain enzymatic functions. Such materials might be responsible for the depression of lymphocyte function.

While these studies have focused on the synthesis of DNA and RNA as essential steps in cellular immunity, Sanders, Luby, Sanford, and Hull in this laboratory have demonstrated suppression of interferon response of lymphocytes to Newcastle disease virus when incubated in uremic sera (24). In that interferon represents a mediator produced by circulating lymphocytes, these parallel studies are corroborative. Other mediators of lymphocytes such as transfer factor, migration inhibitory factor, chemotactic factors, and lymphotoxin have not been assessed.

Observations of lymphocyte function in renal failure have provided important support for the role of this cell type in cellular immunity. Relationships are established between lymphopenia, depressed delayed hypersensitivity, delayed homograft rejection, and the possibility of susceptibility to infections. Certainly, the mechanism by which renal failure produces such profound alterations in lymphocyte functions has not been established. It appears reasonable to conclude that the elucidation of such a mechanism may provide further insight into lymphocyte function and cellular immunity.

The demonstration that a dialyzable factor $(s)$ in the serum of patients with renal failure can greatly modify the function of circulating lymphocytes provides at least a partial explanation for the susceptibility of such patients to a variety of infections. As DNA and RNA synthesis are essential functions of other cells, these observations may be important in considering other metabolic alterations in renal insufficiency. Finally, the demonstration that the milieu in which cells have to fuction may significantly alter their inherent capabilities extends the parameters which have to be included in evaluating host defense capabilities.

\section{ACKNOWLEDGMENTS}

This study was supported by U. S. Public Health Service Research Grant 1 RO1 HD 00851, and Training Grant 1 TO1 AI 00030 from the National Institutes of Health.

\section{REFERENCES}

1. Balch, H. H., Y. Sako, and W. H. Meroney. 1955. Observations on the surgical care of patients with posttraumatic renal insufficiency. Surg. Gynecol. Obstet. 100: 439.

2. Bluemle, L. W., G. D. Webster, and J. R. Elkinton. 1959. Acute tubular necrosis. Analysis of 100 cases with respect to mortality, complications and treatment with and without dialysis. Arch. Intern. Med. 104: 180.

3. Montgomerie, J. Z., G. M. Kalmanson, and L. B. Guze. 1968. Renal failure and infection. Medicine (Baltimore). 47: 1 .

4. Wilson, W. E. C., C. H. Kirkpatrick, and D. W. Talmage. 1965. Suppression of immunologic responsiveness in uremia. Ann. Intern. Med. 62: 1.

5. Wilson, W. E. C., C. H. Kirkpatrick, and D. W. Talmage. 1964. Immunologic studies in human organ transplantation. III. The relationship of delayed cutaneous hypersensitivity to the onset of attempted kidney allograft rejection. J. Clin. Invest. 43: 1881 .

6. Smiddy, F. G., R. G. Burwell, and F. M. Parsons. 1960. The effect of acute uraemia upon the survival of skin homografts. The influence of uraemia upon certain aspects of lymph node reactivity. Brit. J. Surg. 48: 328.

7. Dammin, G. J., N. P. Couch, and J. E. Murray. 1957. Prolonged survival of skin homografts in uremic patients. Ann. N. Y. Acad. Sci. 64: 967.

8. Lang, P. A., S. E. Ritzmann, F. L. Merian, M. C. Lawrence, W. C. Levin, and R. Gregory. 1966. Cellular evolution in induced inflammation in uremic patients. Texas Rep. Biol. Med. 24: 107.

9. Kasakura, S., and L. Lowenstein. 1967. The effect of uremic blood on mixed leukocyte reactions and on cul- 
tures of leukocytes with phytohemagglutinin. Transplantation. 5: 283.

10. Huber, H., D. Pastner, P. Dittrich, and H. Braunsteiner. 1969. In vitro reactivity of human lymphocytes in uraemia-a comparison with the impairment of delayed hypersensitivity. Clin. Exp. Immunol. 5: 75.

11. Silk, M. R. 1967. The effect of uremic plasma on lymphocyte transformation. Invest. Urol. 5: 195.

12. Kirkpatrick, C. H., and W. E. Ruth. 1966. Chronic pulmonary disease and immunologic deficiency. Amer. J. Med. $41: 427$.

13. Black, L., and M. C. Berenbaum. 1964. Factors affecting the dye exclusion test for cell viability. Exp. Cell. Res. 35: 9 .

14. Rogentine, G. N., and B. A. Plocinik. 1967. Application of the ${ }^{51} \mathrm{Cr}$ cytotoxicity technique to the analysis of human lymphocyte isoantigens. Transplantation. 5: 1323.

15. Polesky, H. F., and M. Helgeson. 1970. Viability of lymphocytes in stored blood: response to phytohemagglutinin and to allogenic leukocytes. J. Lab. Clin. Med. 76: 134.

16. Jensson, O. 1958. Observations on the leucocyte blood picture in acute uraemia. Brit. J. Haematol. 4: 422.

17. Riis, P., and J. Stougaard. 1959. The peripheral blood leukocytes in chronic renal insufficiency. Dan. Med. Bull. $6: 85$.
18. Daniels, J. C., H. Sakai, E. K. Cobb, A. R. Remmers, H. E. Sarles, J. C. Fish, W. C. Levin, and S. E. Ritzmann. 1970. Altered nucleic acid synthesis patterns in lymphocytes from patients with chronic uremia. Amer. J. Med. Sci. 259: 214.

19. Lehmann, J. D., J. W. Smith, T. E. Miller, J. A. Barnett, and J. P. Sanford. 1968. Local immune response in experimental pyelonephritis. J. Clin. Invest. 47: 2541.

20. Giovannetti, S., M. Biagini, and L. Ciori. 1968. Evidence that methylguanidine is retained in chronic renal failure. Experientia (Basel). 24: 341.

21. Hicks, J. M., D. S. Young, and I. D. P. Woston. 1964. The effect of uraemic blood constituents on certain cerebral enzymes. Clin. Chim. Acta. 9: 228.

22. Horowitz, H. I., B. D. Cohen, P. Martinez, and M. Papayoansu. 1967. Defective ADP-induced platelet factor 3 activation in uremia. Blood. $30: 331$.

23. Stein, I. M., D. Cohen, D. Burton, and R. S. Kornhauser. 1969. Guanidinosuccinic acid in renal failure, experimental azotemia and inborn errors of the urea cycle. N. Eng. J. Med. 280: 926.

24. Sanders, C. V., J. P. Luby, J. P. Sanford, and A. R. Hull. 1970. Suppression of interferon response in lymphocytes from patients with uremia. In press. 